\title{
A brief review on the accomplishments of the IUGS Commission on Global Sedimentary Geology (C-GSG)
}

Chairman of the IUGS Commission on Global Sedimentary Geology, Director of the Geological Museum, BFSH2-UNIL, CH-1015 LAUSANNE, SWITZERLAND. E-mail: aymon.baud@sst.unil.ch; Tel: +41 21692 44 71; Fax: +41 216924475.

GSGP Website: http://www-sst.unil.ch/gsgp/

The Commission on Global Sedimentary Geology of the IUGS was created in 1987 in response to the need for an international body and a coherent research program to embrace and foster the rapidly emerging field of global sedimentary geology. Since their inceptions, GSGP's two flagship projects, - CRER and Pangea, became a remarkable umbrella for bringing together researchers from around the world. The chief accomplishments and products of the program over the last years comprise successful symposia, workshops and conferences with high quality proceedings and special publications.

The overall objectives of the Commission on Global Sedimentary Geology (C-GSG), originally known and still referred to as the Global Sedimentary Geology (GSGP), were to extend understanding of the history of the earth, surficial processes, the evolution of life, and the biotic influences on earth processes through globalscale research on sediments, sedimentary rocks and their contained organisms and remains. It was also to improve our ability to find, produce and husband natural resources in sedimentary deposits (water, hydrocarbons, minerals, ores, and building materials), and finally to expand and enhance the practice of sedimentary geology through training, exchanges, and cooperative research.

Fitting well with the IUGS policy were the extent of understanding the history of the earth and the extent of cooperative researches.

Since its inception in 1987, the Commission on Global Sedimentary Geology has initiated two major research projects, the CRER Project and the Pangea Project. The CRER Project, which stands for Cretaceous Resources, Events and Rhythms, was the first project. The Pangea Project was the second research project put together by GSGP, the concept of which was originally approved by GSGP's Program Development Committee in January 1991. The Pangea Project was officially launched in a Workshop that was held in May 1992 in Lawrence, Kansas, USA. It was then decided that Project Pangea would focus on the most recent time of supercontinent accretion and dispersal, i.e., from the Carboniferous to the Jurassic, when continents merged toward a geoid low, and much of Pangea's climate appeared to be disposed in an icehouse mode.

The organizational structure of the Commission on Global Sedimentary Geology comprised a Program Development Committee led by a Chairman and assisted by a Vice-Chairman. In addition, national Subcommissions have been established in some countries. The Program Development Committee meets at least every four years during the International Geological Congress. The Commission on Global Sedimentary Geology received funding

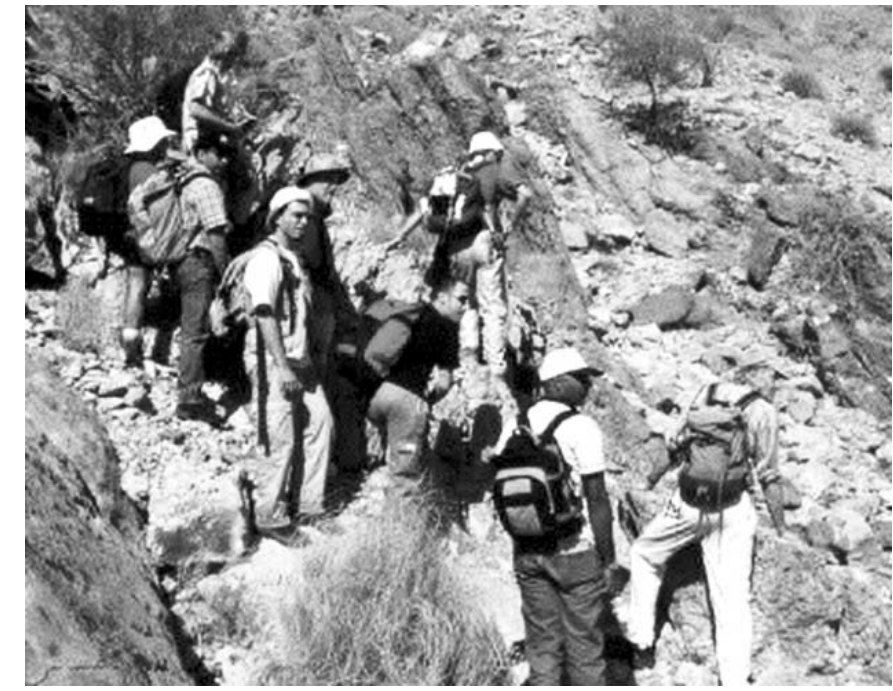

Participants to the Pangea excursion A01 on the Baid late Triassic red limestones of the Oman exotics, January 2001.

from, and reported annually to its parent, the International Union of Geological Sciences (IUGS).

The chief accomplishments and products of the program over the last 6 years (period 1997-2002) were the following:

- 1997 CSPG-SEPM-GSGP Joint Convention: Sedimentary EventsHydrocarbon Systems: 600 presentations, 2500 attendees from 20 different countries.

- A special session on Pangea at the IAS European meeting in Heidelberg, Germany, in the fall of 1997 . The proceedings have been published through the leadership of Lars Stemmerik and Jorg Trappe as a special issue of Paleogeography, Paleoclimatology, Paleoecology, vol. 161/1-2, 292 pages. The issue comprises a dozen papers encompassing various environmental and economic aspects of the super-continent Pangea, from the time it accreted (Carboniferous) to the time it broke up (Jurassic).

- The International Conference on Pangea and the PaleozoicMesozoic Transition (organizers Yin Hongfu and Yang Zunyi of China). This highly successful international Conference was held in Wuhan, Hubei, China, March 9-11, 1999. The proceedings of the Conference with 14 papers (175 pages) have already been published as a University of Wuhan Special Publication.

- A special session on the Permian-Triassic transition at the International Congress on Carboniferous and Permian Stratigraphy in Calgary, Canada, August 1999. Choosen papers have been published in 2002 as part of the Congress' Proceedings Volume.

- Meeting of CRER Working Group 4 was held in ViesteGargano, Italy, September 25-28, 2000. The theme of the meeting was Quantitative Models on Cretaceous Carbonates and the Eastern Margin of the Apulia Platform. It was co-sponsored by 


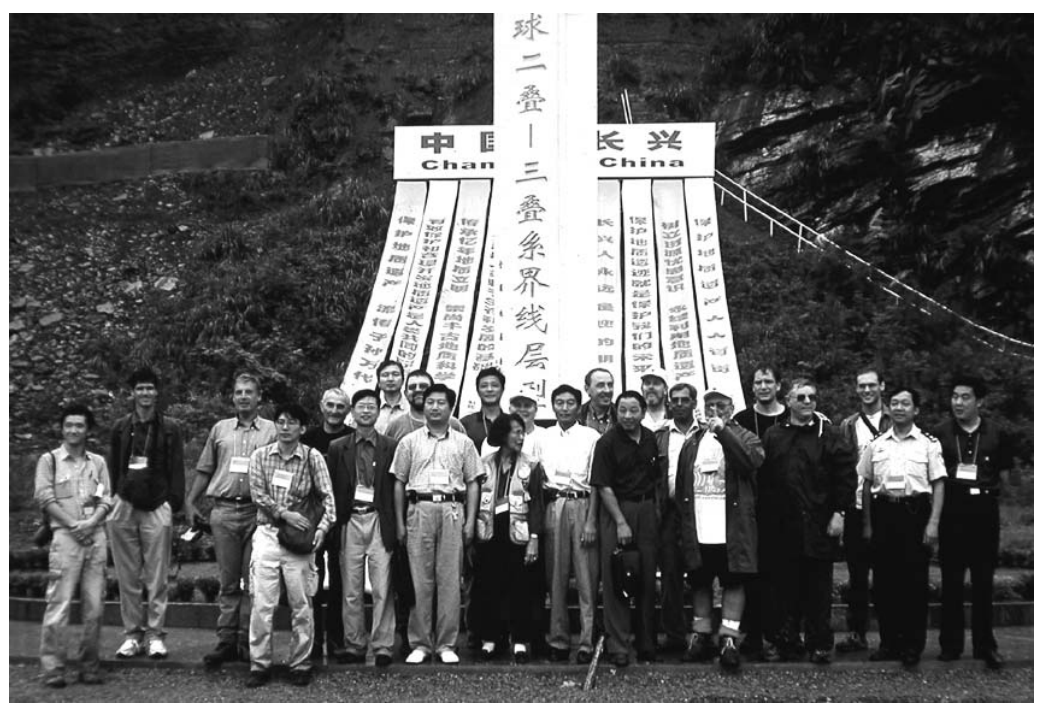

About the second new project "Global Ancient Oceanic Environments and Events (GAOEE)", the leader Prof. Dr. Peter O. Baumgartner was not able to go forward with his project during the last 2 years and also not in a close future.

Apart from these, the chief problems encountered these last two years were, on the one hand, the weak contribution of IUGS to our commission. On the other hand, in a letter from the new IUGS General Secretary dated 12 May 2002, I was informed that the new IUGS rules are specifying that the IUGS Commission should not normally last more than 16 years and therefore our GSGP should be terminated.

As written by Benoit Beauchamp, the former GSGP Chairman, the Commission on Global Sedimentary Geology was created in response to the need for an international body and a coherent research program to embrace and foster the rapidly emerging field of global sedimentary geology. Yet, and in spite of an over ambitious agenda and under funding, GSGP and its two first projects

Participants to the International Symposium on the Global Stratotype of the Permian-Triassic Boundary co-sponsored by GSGP in the Meishan quarry, S. China, August, 2001. have, over the years, became a remarkable umbrella for bringing together researchers from around the world. The solid concepts behind these two projects have acted like unifying forces to bring under the same roof, scientists from third-world and developing countries and

the International Association of Sedimentologists (IAS), the Society of Sedimentary Geology (SEPM) and the Società Geologica Italiana (SGI). This meeting brought researchers from around the world to understand the dynamics of Cretaceous carbonate platforms.

- Meeting of CRER Working Group in Marseille, May 2001. The theme of the meeting was Anatomy of Carbonate bodies.

- Meeting and three field excursions of the Oman Pangea Symposium in Muscat held at the Conference on the Geology of Oman, in January 2001 and production of three field guides. A Report on the Oman Pangea Symposium held at Muscat, January 2001 was published in Episodes 24/2. A special volume of the proceeding of the Oman Pangea Symposium is in press in Palaeogeography, Palaeoclimatology, Palaeoecology.

- Participation of the Pangea Program and GSGP Chairman to the organizing Committee of the International Symposium on the Global Stratotype of the Permian-Triassic Boundary and the Paleozoic-Mesozoic Events held in Changxing, Zhejiang Province, China, August 2001. The proceedings have been published (see below).

- Meeting of GSGP interested scientists and PDC members during the IAS international Conference held in Davos, September 2001.

- Meeting of GSGP interested scientists and PDC members during the IAS international Conference held in Johannesburg, July 2002.

- Updating the web site for GSGP.

All these successful last years' accomplishments and products came partly from one project, the Pangea project; from the CRER project, only the Working Group 4 is still active through a Web newsletter and various meetings.

In 2000, at the 31st IGC in Rio, we proposed two new flagship projects. the first was "Sedimentary environments of East Asia Mesozoic deposits (SEAMD)" under the leadership of Prof. Dr. Paul Markevich, Far East Geological Institute, Vladivostok, Russia. The second concerned "Global Ancient Oceanic Environments and Events (GAOEE)" under the leadership of Prof. Dr Peter O. Baumgartner, Geological Institute, Lausanne University, Switzerland.

After discussion during the IAS Congress in Johannesburg last July we arrived to the decision that the Markevich project was not global and fit better with the IGGP policy. researchers from the rich nations. This synergy has taken the form of symposia, workshops and conferences that resulted in high quality publications wherein all aspects of the Commission's three terms of reference have been explored and fulfilled. No better example than this were the three organized International Conference on Pangea and the Paleozoic-Mesozoic Transition, a bona fide Pangea Project's activity. The first one held March 1999 in Wuhan, China, attracted a large international contingent along with a large number of Chinese geoscientists. The second one, held January 2001 in Muscat, Oman, during the Conference on the geology of Oman, attracted also a large international contingent along with a large number of Middle-East geoscientists.

But a success story has to have an end and no one new flagship projects will come after. My wish is that the International Union of Geological Sciences (IUGS) will not forget to include the global aspect and contribution of the dynamic of sediments, sedimentology and sedimentary geology in a future a new task force or in a new Commission.

\section{Main publications:}

Baud, A., Beauchamp, B., Marcoux, J. and Twitchett R. (in press): The Oman Pangea Symposium. A special issue of Paleogeography, Paleoclimatology, Paleoecology.

It is the result from a Pangea Symposium held during the Conference on the Geology of Oman at Muscat, Jan. 12-16, 2001. The six papers collected in this special issue broadly cover two main themes: Pemian and Triassic stratigraphy and depositional models in Oman and Pangean stratigraphy, paleoclimatoloy and paleobotanics beyond Oman.

For the Pangea excursions before and after the Conference, the following 2 guide books have been published and concerned recent progress in the Permo-Triassic outcrop studies in Oman:

Baud, A., Béchennec, F., Cordey, F., Krystyn, L., Le Métour, J., Marcoux, J., Maury, R., and Richoz, S., 2001a, Permo-Triassic Deposits: from the Platform to the Basin and Seamounts, Conference on the Geology of Oman, Field guidebook, Volume Excursion A01: Muscat, Oman, 54 p.

Baud, A., Béchennec, F., Cordey, F., Le Métour, J., Marcoux, J., Maury, R., and Richoz, S., 2001b, Permo-Triassic Deposits: from Shallow Water to Base of Slope, a guidebook, Conference on the Geology of Oman, Field guidebook, Volume Excursion B01: Muscat, Oman, 40 p. 
Beauchamp B. (Compiler), 1997. Program with abstracts. CSPGSEPM-GSGP Joint Convention, 1997. Sedimentary EventsHydrocarbon Systems. Calgary, Canada, June 1-6, 1997.

More than 600 presentations, 2500 attendees from 20 different countries.

Dean and Arthur (Eds.), 1999. Stratigraphy and Paleoenvironments of the Cretaceous Western Interior Seaway, USA. Volume No. 6 in the SEPM (Society for Sedimentary Geology) series Concepts in Sedimentology and Paleontology.

This volume presents the results of a coordinated, multidisciplinary and broadly sponsored (academic, industry, USGS) study of Cretaceous carbonates and clastic rocks in cores collected along a transect across the old Cretaceous seaway in North America. This 255 page volume comprises thirteen papers that particularly focus on a series of units in cores from six drill holes from western Kansas, southeastern Colorado and eastern Utah.

Embry, A.F., Beauchamp, B., and Glass, D.J. (Eds.), 1993. Pangea, Global Environments and Resources. Canadian Society of Petroleum Geologists, Memoir 17, 982 pages.

Proceedings of the 1993 GSGP-CSPG Joint Convention (Pangea Conference), Calgary, Canada, August 15-19, 1993.

More than 370 presentations and 1500 attendees from 18 different countries.

Ginsburg, R.N. and Beaudoin, B. (Eds.), 1990. Cretaceous Resources, Events and Rhythms, Background and Plans for Research. NATO ASI Series, Series C: Mathematical and Physical Sciences-Vol. 304, Kluwer Academic Publishers, London, 352p.

Proceedings of the Digne 1988 meeting.

Hills, L., Henderson, C., and Bamber, E.W (Eds), 2002. Carboniferous and Permian of the World. Proceeding of the XIV International Congress on the Carboniferous and Permian, Calgary 1999, Canadian Society of Petroleum Geologists, Memoir 19, 947pp.

During this Congress held in Calgary in August 1999 was a special Pangea session on the Permian-Triassic transition.

Karvonen, R., Den Haan, J. Jang, K., Robinson, D., Smith, G., Webb, T. and Wittenberg J. (Eds.), 1993. Carboniferous to Jurassic PANGEA - Guidebook. Core workshop, Calgary, Alberta, Canada, August 15-19, 1993.

Project PANGEA Workshop 1992. Program, abstracts and field guide book. Lawrence Workshop, Kansas, USA, May 23-28, 1992.

Klein, G.D. (Ed.), 1994. Pangea: Paleoclimate, Tectonics, and Sedimentation During Accretion, Zenith, and Breakup of a Supercontinent. Geological Society of America, Special Paper 288, 295p.

Proceedings and recommendations of the 1992 Lawrence Workshop, as well as those of a kick-off Pangea session that was held on May 24, 1992 at the GSA Annual Meeting in San Diego.

Stemmerik and Trappe (Eds ), 2000. Pangea. A special issue of Paleogeography, Paleoclimatology, Paleoecology, vol. 161/1-2, $292 \mathrm{p}$.

It is the result from a special session held during the 18th IAS Regional European Meeting in Heidelberg, September 1997. contribute further to the knowledge gathered as the result of three previous Pangea conferences (Klein, 1994; Embry et al., 1994; Yin and Tong, 1999). The papers broadly cover two main themes: Regional to global paleogeographic reconstructions and Triassic depositional systems, all aiming to increase our knowledge of Pangea.
Wood, J. and Martindale, B. (Compilers), 1997. Core Conference. June 5-6, 1997. CSPG-SEPM-GSGP Joint Convention, 1997. Sedimentary Events - Hydrocarbon Systems. Calgary, Canada, June 1-6, 1997.

Yin, H., Tong, J., and Campi, M.J. (eds), 2002, International Symposium on the Global Stratotype of the Permian-Triassic Boundary and the Paleozoic-Mesozoic Events, in Journal of China University of Geosciences, Volume 13/2 (Special Issue), 107p., Wuhan.

This volume presents 12 papers collected after the. International Symposium on the Global Stratotype of the Permian-Triassic Boundary and the Paleozoic-Mesozoic Events held in Changxing, Zhejiang, China.

Yin Hongfu and Tong Jinnan (Eds.), 1999. Proceedings of the International Conference on Pangea and the Paleozoic-Mesozoic Transition. March 9-11, 1999, China University of Geosciences, Wuhan, Hubei, China. China University of Geosciences Press, 175p.

Dr. Aymon Baud is the Director of the Geological Museum in Lausanne (Switzerland). Working in the Alpine Triassic stratigraphy and sedimentology he received his doctorate from the Lausanne University in 1984. From 1989 to 1996 he was the chairman of the international Subcommission on Triassic Stratigraphy. From his interests and publications on the Permian-Triassic boundary events and his active participation to the Pangea Project of the Global Sedimentary Geology Program (GSGP) he was asked to succeed to Dr. Benoit Beauchamp to the chair of the Global Sedimentary Geology Commission of the IUGS and appointed in 2000 by the IUGS General Assembly. 